\title{
Development Of Non-Formal Primary School Education Tutor In Facing The Era Of Industrial Revolution 4.0 In Sukabumi City
}

\author{
Iis Nurasiah*1, Dyah Lyesmaya ${ }^{2}$, Aidah Ananta ${ }^{3}$, Deden Sumiarsa ${ }^{4}$, Dian Ashlan ${ }^{5}$ \\ 1,2,3 Universitas Muhammadyah Sukabumi \\ ${ }^{4}$ SDN Cibungur Kota Sukabumi \\ ${ }^{5}$ PKBM Ummi-Kulsum
}

\section{A R T I C L E I N F O}

\section{Article history:}

Received 19 August 2018 Received in revised form 19 September 2018 Accepted 25 Oktober 2018 Available online 29

November 2018

\section{Keywords:}

Non-formal primary school education, Tutor, Sukabumi City

\section{A B S T R A CT}

The rapid movement of information technology becoming one of many factors for developing education. This factor is more important today because nowdays we are increasingly unable to separate our lives from information technology. education is one of the elements affected by the rapid growth of information technology. like it or not we have to balance and adapt to this growth. The Center for Community Learning Activities (PKBM) is an alternative choice for getting an education outside of formal education. In Sukabumi the existence of PKBM needs to be developed and modernized because it has not been touched by professionals. PGSD's dedication team answered this challenge by providing assistance and training at two PKBMs in the city of Sukabumi. the methodology carried out includes five stages, namely, group selection, socialization, training, reflection, and monitoring and evaluation. The program result is Collaboration between PKBM managers and PGSD Study Programs UMMI helped develop NonFormal Elementary School Education programs in Sukabumi City.

\footnotetext{
* Corresponding author.

E-mail addresses: iisnurasiah@ummi.ac.id (Nurasiah Iis)
} 


\section{Introduction}

We are entering the industry age 4.0 now. Industrial age 4.0 makes the economy based on knowledge and technology. The development of information, communication and technology creates a stream of globalization that is increasingly reaching the world. The era of industrial revolution is an age of knowledge and technology. At present, a person's abilities and skills in the intellectual, social, knowledge and life skills aspects determine whether a person can survive or not in this era. In addition, the ability to compete and adapt is an important capital in order to survive in the large market of this century of knowledge. Therefore, it is necessary for people who are able to learn as long as life, so that no one is neglected in gaining knowledge and life skills.

Law No. 20/2003 on the National Education System states that non-formal education functions to develop the potential of students with an emphasis on mastering functional knowledge and skills and developing professional attitudes and personalities. Non-formal education is equivalent to formal education after going through an equalization assessment process by a government-appointed institution that refers to national education standards. (Kamil; 2009). Non-formal education is a pathway to education outside formal education that can be carried out in a structured and serves to develop students commpetencies with an emphasis on academic knowledge and functional skills and the development of professional attitudes and personalities (Diyanti, 2014). Another definition of equality education is the path of non-formal education with graduate competencies that are the same as formal schools, but the content, context, methodology and approach to achieving competency standards of these graduates provide more concepts to practice work-oriented life skills or self-help (Directorate of Equality Education, 2004.a: 3-4)

The people of Sukabumi City, especially in remote villages, have high rates of illiteracy and lack of skills. They generally have difficulty accessing formal education because of economic factors. On this reason, the Umi Kulsum Foundation and Al-Amien took the initiative to establish a Community Learning Activity Center (Pusat Kegiatan Belajar Masyarakat/PKBM). Their mission is to educate and bring up not only orphans but also abandoned and underprivileged children through this PKBM. The children who came to PKBM consisted of various age groups and from various regions, not only around the City and Regency of Sukabumi but from all parts of Indonesia. These two foundations are very strategic in helping to realize community skills by reason of: (1) being in an area that is conducive to teaching and learning, (2) having human resources in teaching and assisting the community, and (3) high public interest in participating in PKBM. Besides Both PKBM, are located not far apart even though both are in different subdistricts. For this reason, we choose them to be our service partners.

PKBM in both of our partners has a Kejar (Learning Group) program for non-formal junior secondary school (Paket B) and high school (Paket C). Whereas for Pursuing Non-Formal Primary School Education (Paket A) does not yet exist. In this current year, there are 25 people who have registered (Paket A) from around Nanggeleng Sub-District and around 20 people in Cibeureum Subdistrict, but they do not get Non-Formal Primary School Education services because they are not yet available in both PKBM. In fact, each year the participants' interest in participating in Non-Formal Elementary School Education is increasing.

In carrying out the above program there are major obstacles faced by PKBM Ummi Kulsum, namely limited supporting facilities such as the elementary curriculum, the very narrow place of the course, the absence of non-formal elementary school education tutors, and there are some participants who lack information technology knowledge like computers and digital skills. These constraints were handled by PKBM Ummi Kulsum by empowering the human resources they owned.

PKBM Ummi Kulsum conducts community empowerment with the service team through the Elementary School Tutor Teaching Training program according to the 2013 curriculum. As explained above, tutor teaching skills at the elementary school level have very good prospects for realizing the welfare of the poor but have teaching skills, especially skills teach elementary school age children so that they can create a business opportunity for Tutoring (Bimbel), with the following reasons: (1) there are still many Tutoring Guides that do not have professional human resources, (2) Learning Guidance in the Sukabumi city only can be followed by middle to upper class economists, (3) the location of Tutoring is quite far and requires expensive costs, (4) the development of information technology as a support for teaching skills is very promising to build a Learning Guidance business that can be followed by elementary school children around PK BM. As a step in strengthening and developing Non-Formal Primary School Education, partners are needed. Based on the results of a survey and discussion with the PGSD Community Service Team of Muhammadiyah Sukabumi Program, that partners who have the same entrepreneurial spirit, complement each other for the availability of raw materials, complement each other's available resources, and benefit each other economically, Al Orphanage Amien for the following 
reasons: (1) Geographically PKBM Al-Amien with the Ummi Kulsum Foundation is very close, so that access to building relationships is very smooth, (2) Both institutions have the same understanding of the direction of business development, (3) Ummi Kulsum Orphanage has a building that can be used by PKBM Al Amien, (4) Ummi Kulsum Foundation has many partners with educational institutions that PKBM Al Amien can use as a place to develop Non-Formal Elementary School and Tutoring Education, (5) Ummi Kulsum foundation has HR which can be empowered as a tutor at PKBM Al Amien, and (6) Ummi Kulsum foundation se others accommodate orphans as well as accommodating the poor who can be used as a charity field for servants and the surrounding environment. This collaboration is expected to be able to develop Non-Formal Elementary School Education programs and be able to realize Learning Guidance efforts for tutors who have been trained and nurtured by the service team organized by PKBM Ummi Kulsum.

Regarding the potential of partners, our service team provides training to prospective Learning Group (kejar) tutors for Non-Formal Primary School Education. According to Adhi (2015) based on Government Regulations stipulated in accordance with Ministerial Decree No. 0132/U/2004 concerning Paket A which is described in the form of Guidelines for Implementing Non-Formal Elementary School Education Programs in 2010. Moheriono (2012: 95) states "performance is a picture of achieving the level of achievement of an activity program or policy in realizing goals, objectives, vision and the organization's mission as outlined in the strategic planning of an organization". T.R Mitchell in Sedarmayanti (2001: 51), states that "performance is influenced by several aspects that can be used as a tool to measure performance", namely: (1) Quality of work, (2) Timeliness, (3) Initiative, (4) Ability, and (5) Communication. The implementation of performance measurement is done by gathering information relating to the matter under investigation for some time and comparing the results with the standards that have been made so that it can be seen the performance of a person.

The term educator in non-formal education is better known as tutors. In etymology, tutors are private teachers, extra teaching staff or provide tutoring/teaching. The meaning of educators is qualified educational staff as teachers, lecturers, counselors, tutors, widyaiswara, tutors, instructors, facilitators and other designations that are in accordance with their specialty, and participate in conducting education. Where the tutor is a term for people who teach in non-formal education, even though the tutor is a teacher in formal education. Tutors are educators in Nonformal Education (PNF). Tutors are teachers who are in charge of early childhood education, equality education, and literacy education. Because the psychological development of students is still so early, the task of educators is more as caregivers (pamong).

Mustafa Kamil, (2007: 13) states that "tutors in non-formal education are professionals who have the ability, competence and skills in managing the learning process, so that a tutor is required to have the ability and expertise in accordance with his teaching qualifications and in accordance with the basic tasks that have been predetermined. The main tasks of the tutor according to Ministerial Decree No. 0132 / U / 2004 Concerning Non-Formal Primary School Education described in the form of a book for the Implementation of the General Non-Formal Elementary School Education Program in 2010 (2010: 14), are: (1) Identify needs, (2) arrange learning plans, (3) Carry out the learning process, (4) Choose a method and carry out learning according to the domain you want to achieve (knowledge, attitudes and skills), (5) Motivating students, (6) Select, compile or develop media / learning materials, (7) Administering learning activities, and (8) Assessing learning outcomes. The surrounding community that has a passion or desire to become a tutor is quite a lot but their educational background varies so that the standard is needed to become a tutor. While the number of participants participating in the kejar of Non-Formal Elementary School Education is always available for each year. Whereas guidance is provided (Bimbel) is also needed for the community around the PKBM location. So, we conduct training and mentoring for human resources who are able to provide education services and are able to prosper them economically.

As for equality education, the learning system is conceptualized as an active learning system of students. Tutor is a guide and motivator for students to learn on their own learning modules. The equality education tutor is tasked with guiding students to actively study the teaching material presented in the module. (Sulisyaningsih, 2013) Thus, equality education tutors are more of a supervisor/motivator than teachers who teach.

A teacher of non-formal education (tutor) should also be able to behave like a formal school teacher, so that the equality education program that becomes his field of work can be truly equivalent to formal education. Thus, graduates are ready to continue to higher education or are ready to enter the workforce to compete for jobs, even ready to work independently. So it is not too wrong if each tutor needs to be equipped with a set of knowledge, skills and attitudes to support the performance", such as: 1 . Having an educational background that is in accordance with his field of duty; 2. Having the competencies needed in accordance with the field of duty; 3. Having the opportunity to develop his professionalism through various training and workshops. 
For those various reasons above, this service is present, namely to improve the quality of nonformal primary school education through improving the quality of tutors by conducting mentoring and training on learning.

\section{Methods}

The method used in this service activity is training and mentoring. The set of activities agreed upon between the implementers of community service activies at PGSD UMMI and PKBM Ummi Kulsum and PKBM Al Amien were training in the identification and development of curriculum and skills training in delivering teaching materials. The implementation method offered to support the implementation of this program is carried out through five stages. Stage 1 is Group Selection. Group Selection is the formation of Posdaya as manager of the Kejar of Non-Formal Primary School Education in the form of the Non-Formal Elementary School Education Posdaya. This Posdaya will be accompanied by the proponent and periodic monitoring is carried out every month for a year to be sustainable. Stage 2 is Activity Socialization. The second phase aims to make program participants who are members of partners get an overview and benefits related to the implementation of the program to be implemented. Stage 3 is Learning Training. The training material contains, (1) Identification of curricula in elementary schools, (2) Training on developing teaching materials, and (3) Training on developing instruments to implement teaching materials. Stage 4 is Reflection. At this stage prospective tutors can implement learning tools and teaching materials. When conducting mentoring, prospective tutors are accompanied by a service team in providing classroom learning. After carrying out the learning process, prospective tutors and service teams conduct an evaluation and reflection of the effectiveness of the implementation activities that have been carried out. Stage 5 is Monitoring and Evaluation. Monitoring and evaluation is an activity to see and assess the effectiveness of activities can go according to plan, and to assess the level of success and continuation of this service activity.

The indicators of the success of this activity are the implementation of all training activities in accordance with what was planned. In addition, also (1) produce learning devices from the development of the PKBM curriculum for Non-Formal Elementary School Education and Tutoring, (2) produce teaching materials to be used in both partners, (3) Increase the teaching ability of tutors, (4) Increase the ability of elementary school tutors and in the development of teaching materials, (5) produce rules and regulations for PKBM Non-Formal Primary School Education, (6) Establishment of tutoring institutions according to the ability of tutors in PKBM Non-Formal Primary School Education

\section{Result and Discussion}

The results of the Community Service program are obtained through five stages. An explanation of the results of each activity at each stage is described as follows.

\section{Stage 1. Group Selection}

Tutors consisting of 10 people were divided into two to become Tutors at PKBM Ummi Kulsum and PKBM Al-Amien. Grouping is adjusted to the latest education owned by tutors. A list of group names is listed below.

Table 1. List of Names for Tutors for Non-Formal Primary School Education

\begin{tabular}{|c|c|c|}
\hline No & Name & Education \\
\hline 1 & Siti Maysaroh & High school \\
\hline 2 & Hana & High school \\
\hline 3 & Husen & High school \\
\hline 4 & Ali & High school \\
\hline 5 & Aidah Ananta & $3^{\text {rd }}$ grade student of PGSD UMMI \\
\hline 6 & Hainun & $3^{\text {rd }}$ grade student of PGSD UMMI \\
\hline 7 & Wiwit & $3^{\text {rd }}$ grade student of PGSD UMMI \\
\hline 8 & Tami & $2^{\text {nd }}$ grade student of PGSD UMMI \\
\hline 9 & Nisa & $2^{\text {nd }}$ grade student of PGSD UMMI \\
\hline 10 & Mira & $2^{\text {nd }}$ grade student of PGSD UMMI \\
\hline
\end{tabular}




\section{Stage 2. Dissemination of Activities}

The stages of socialization are the stages of presentation on the legal basis and activities contained in the Non-Formal Elementary School Education program. The explanation in question is the presentation of the types and activities of Non-Formal Primary School Education. We inform that this tutor training program for Non-Formal Primary School Education consists of three topics, namely self-development, teaching practice, and innovative work. These three topics can be done by means of functional training, tutors' collective activities, discovering technology, artwork, developing tools, materials, guidelines, modules and so on. Based on the results of the socialization it was found that self-development had been carried out by tutors and had been programmed well from the school level to the service level. Most tutors already understand this.

As for the topic of innovative work, the results of this socialization discussion recommended recommending training and mentoring for the creation of innovative work, which is about making teaching plans, presentation materials, making questions, and evaluating. However, before giving assistance to the creation of this innovative work, we extracted information, it turns out that most of the tutors did not know about the right teaching strategies for Non-Formal Elementary School Education participants who had different age backgrounds. In addition, when given questions about preparation for learning, the tutor had difficulty in making it, so participants and facilitators concluded that it was necessary to conduct training and mentoring for the creation of learning devices.

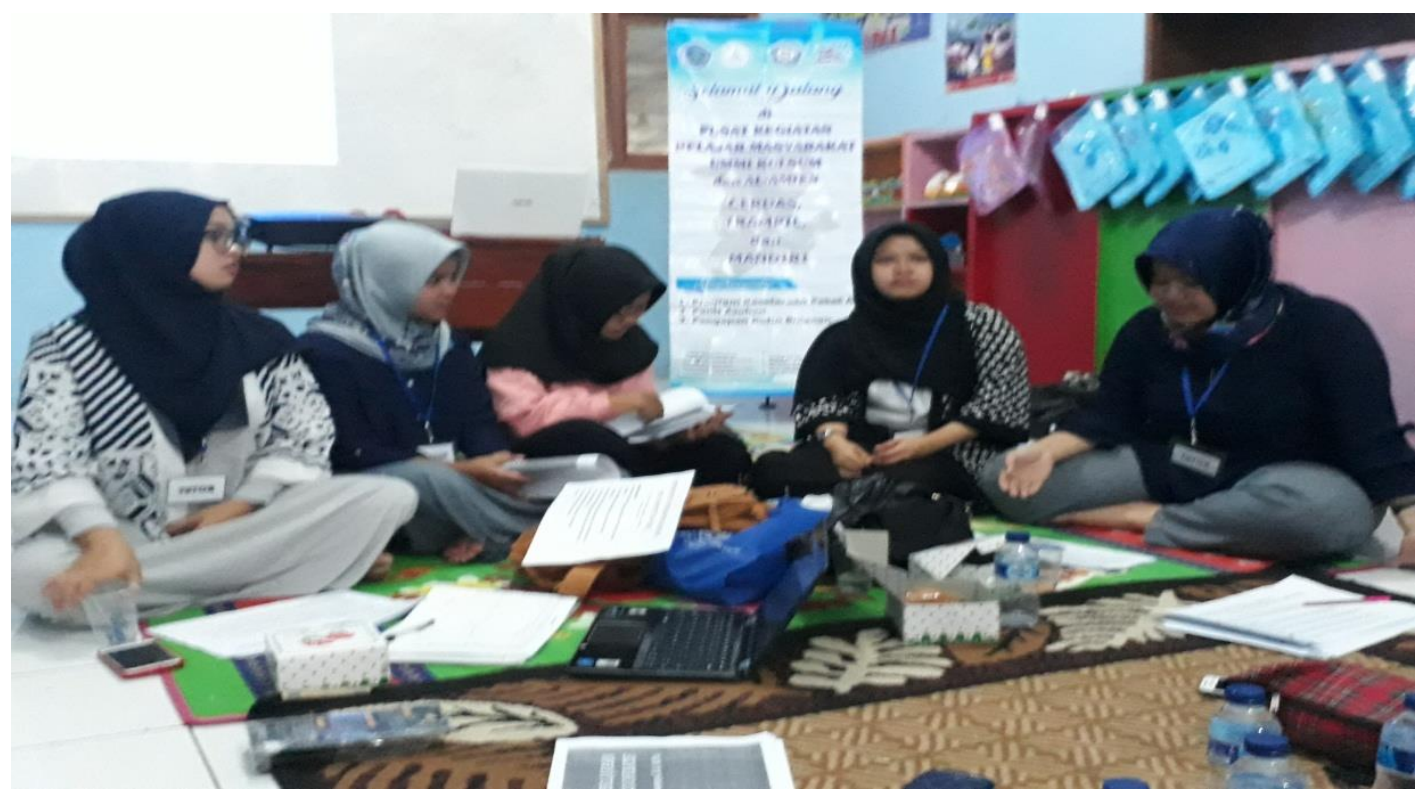

Figure 1 Training of Non-Formal Elementary School Tutors in Producing Innovative Learning Media

\section{Stage 3. Training}

Stages of Training are stages that are carried out after planning and socialization are carried out. The stages of training that have been adjusted to the results of the discussion at the socialization stage, namely training on strategies in learning. Learning training is carried out after the socialization of Non-Formal Elementary School Education in Non-Formal Elementary School Education is completed in the Hall of Ummi Kulsum Non-Formal Elementary School Education in the City of Sukabumi. The training is carried out by describing how good learning and participants examine the learning examples provided by the facilitator.

The results of the training obtained data that all tutors had made teaching preparation and difficulties in teaching materials and appropriate strategies to deal with students with different age backgrounds. 


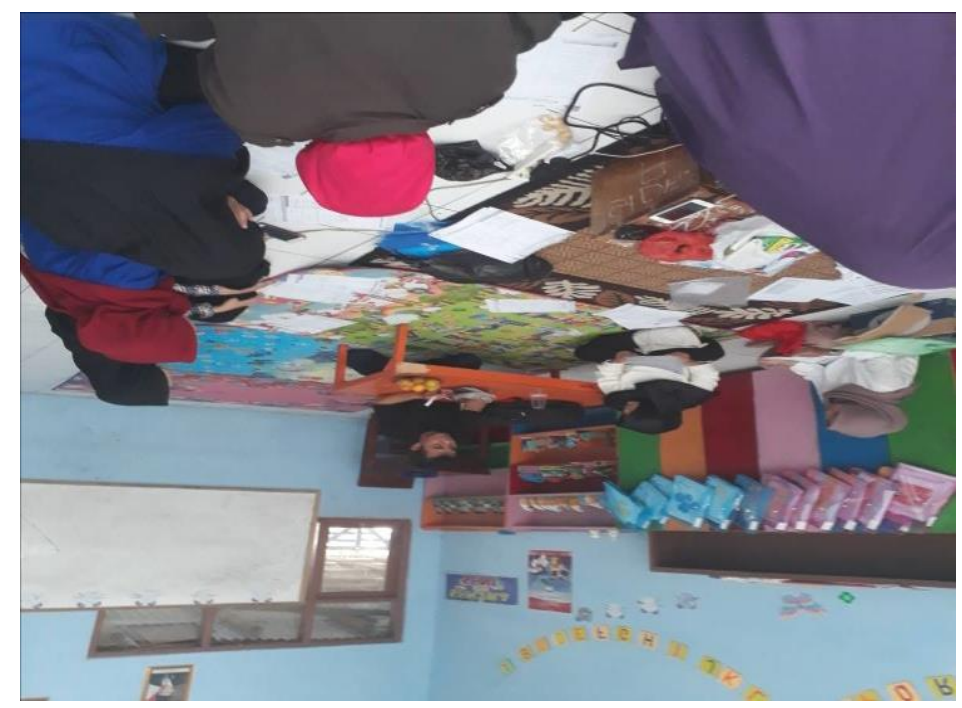

Figure 2. Training of Non-Formal Elementary School Tutors with Cibungur Teachers Tricks for Facing USBN

\section{Stage 4. Reflection}

During the Reflection phase, discussion/feedback and feedback or follow-up from the stages of training and mentoring were conducted in two places of Non-Formal Primary School Education in the city of Sukabumi. At this stage we reflect on the Non-Formal Elementary School Education program. The results of reflection show that the assistance and development activities of Non-Formal Elementary School Education in Non-Formal Primary School Education are very useful to improve the professionalism of tutors. Activities in Non-Formal Elementary School Education require time and assistance from UMMI, especially regarding mentoring and training in learning strategies. In addition, the result of reflection is that the tutor has difficulties in the placement of learning strategies and the need for lesson study with mentoring assistance.
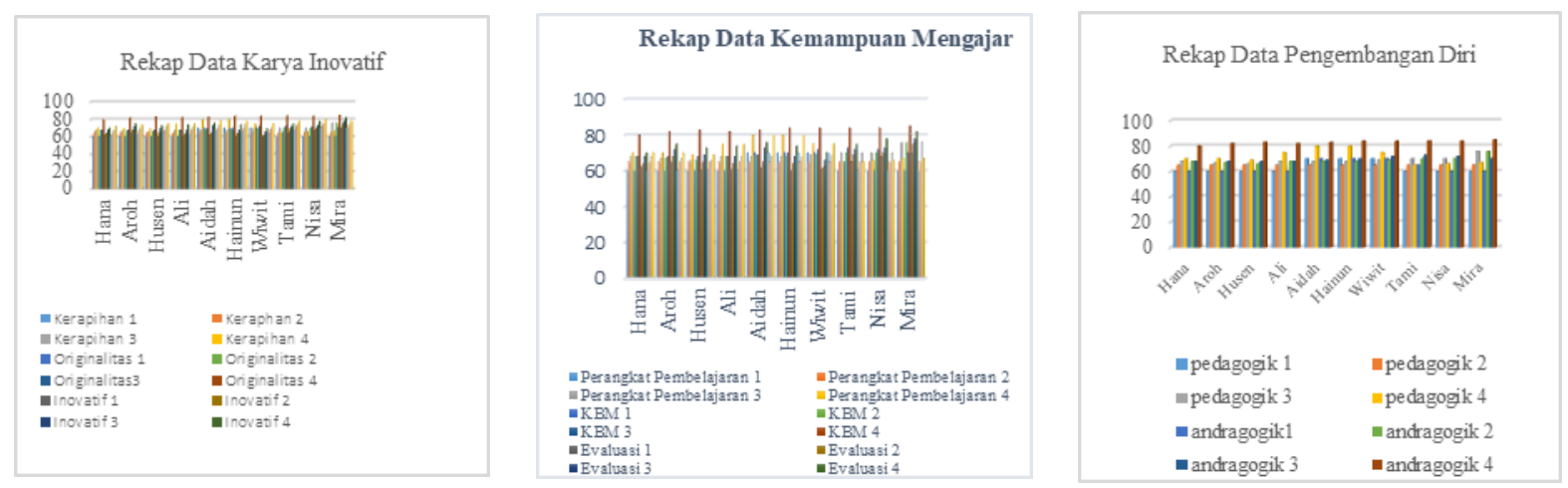

Figure 3. Recapitulation of Data on Competence Results of Non-Formal Elementary School Education Tutors 


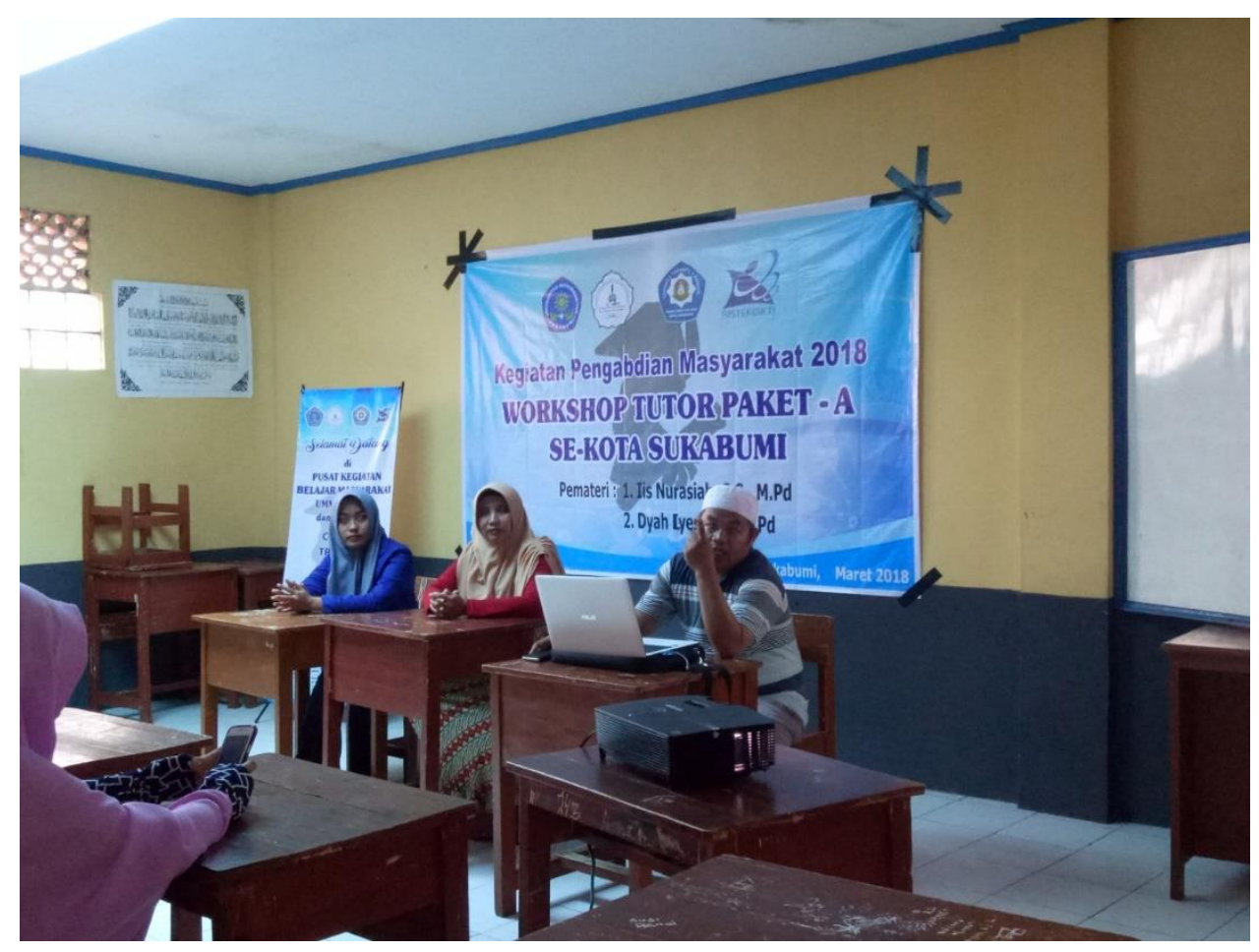

Figure 4. Monitoring and Evaluation Activities

\section{Stage 5. Evaluation and Monitoring}

The monitoring and evaluation that has been carried out is as follows.

1. Documents Learning tools from the development of the PKBM curriculum for Non-Formal Primary School Education; (Attached)

2. Documents for teaching materials to be used in both partners in the form of modules; (attached)

3. Increased teaching ability of tutors;

4. Increased ability of elementary school tutors and in the development of teaching materials;

5. PKBM Regulations and Regulations for Non-Formal Primary School Education;

6. Establishment of tutoring institutions according to the ability of tutors at PKBM Non-Formal Elementary School Education named Bimbel Perseda.

The results of community service are as follows.

1. MOU between PKBM Ummi Kulsum and PGSD Study Program at Muhammadiyah University Sukabumi;

2. Establishment of Tutoring which is managed by tutors of Non-Formal Primary School Education under the guidance of PKBM Ummi Kulsum. 


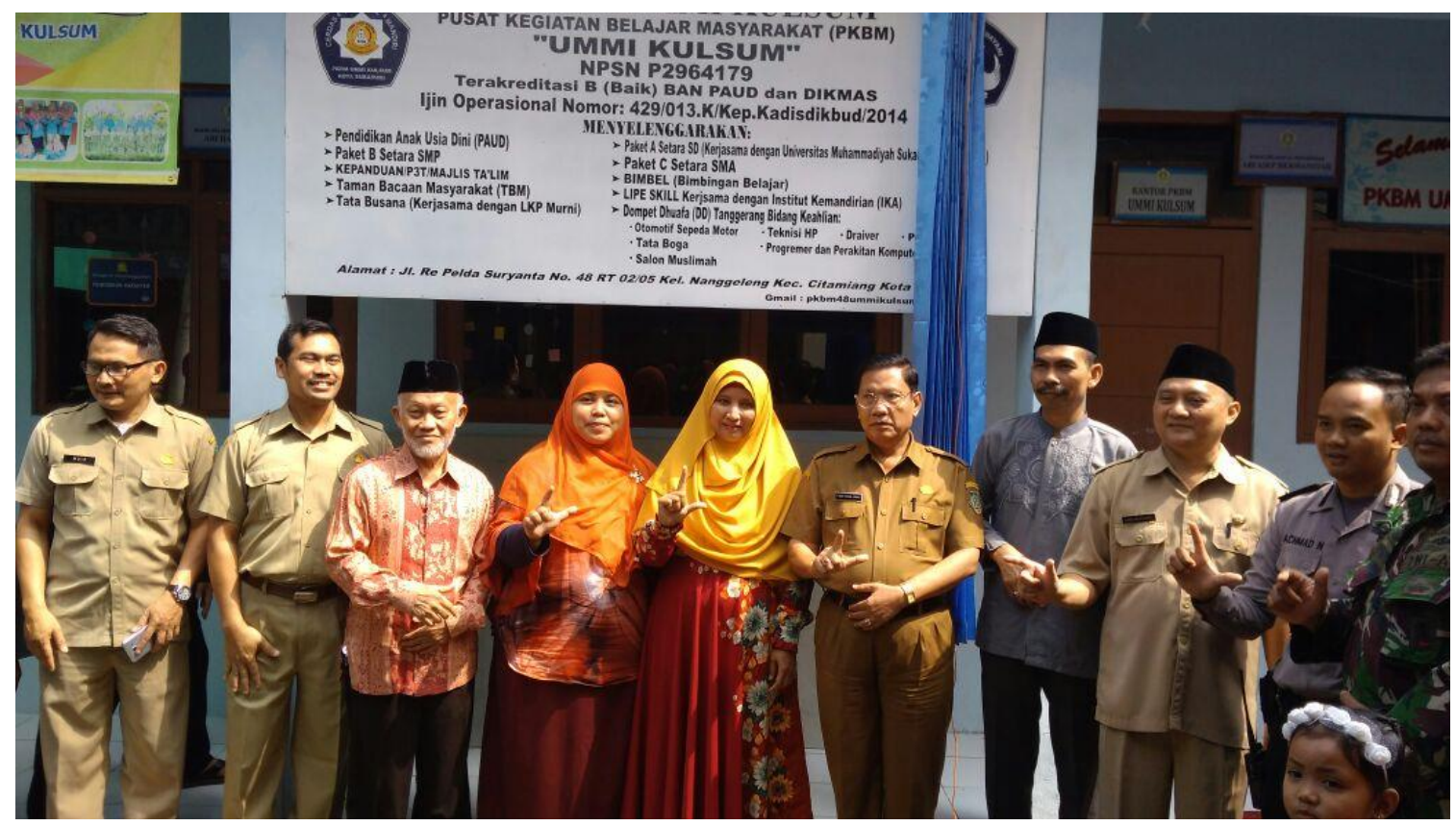

Figure 5. Inauguration of Non-Formal Primary School Education by the Head of National Education Office of the City of Sukabumi

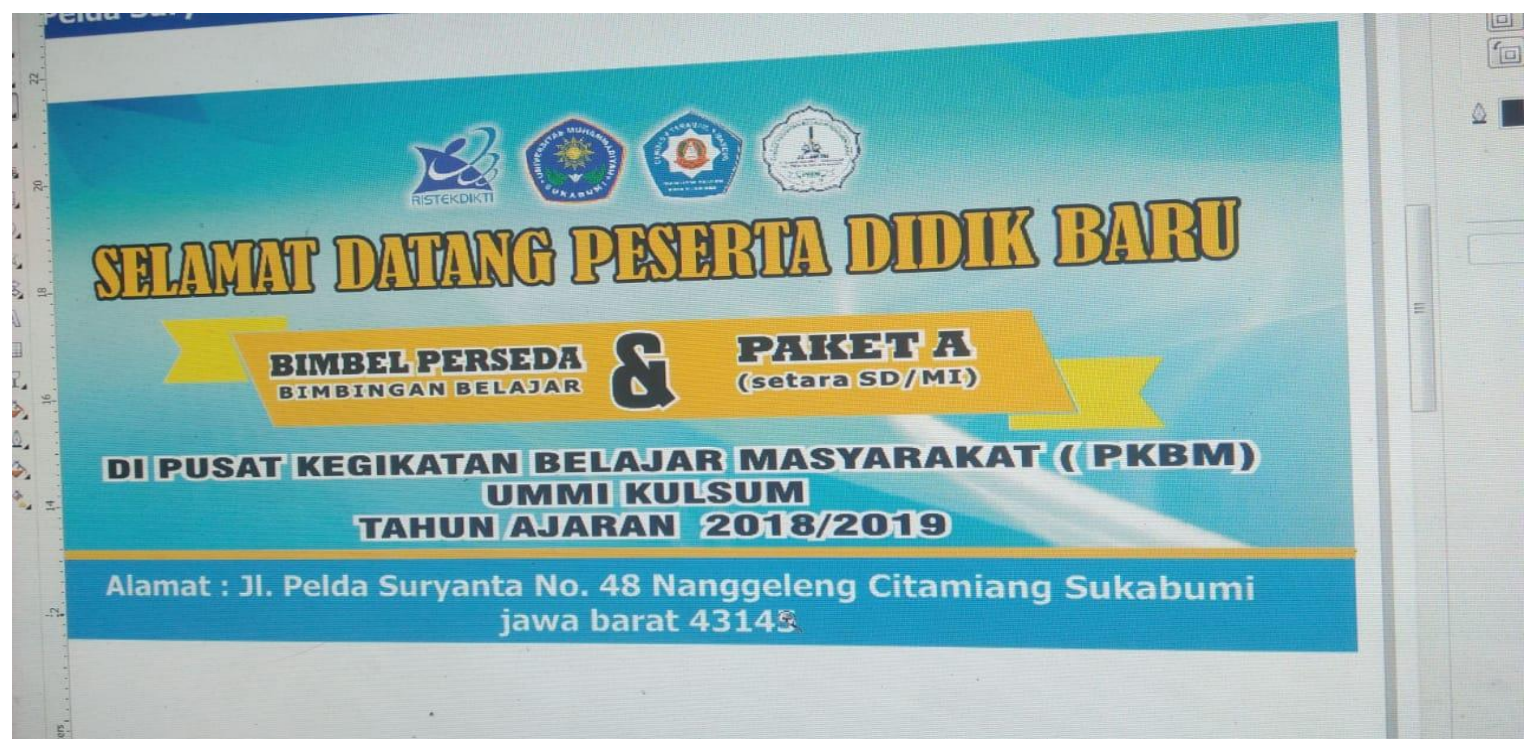

Figure 6. Bimbel PERSEDA

\section{Conclusions}

Based on problem identification, partner analysis, and training and mentoring that we did, it can be concluded: 1 . The knowledge of tutors who have different educational backgrounds causes varied tutor competencies, 2. Mentoring and training can increase the enthusiasm and motivation of tutors and students, 3. Collaboration between PKBM managers and PGSD Study Programs UMMI helped develop Non-Formal Elementary School Education programs in Sukabumi City.

\section{References}

Adhie Putra Arya Dwinata,(2010). Hubungan Kinerja Tutor Dengan Prestasi Belajar Warga Belajar, E Jurnal UNS 
Depdiknas. (2008). Undang-undang No. 3Tahun 2008 tentang Standar ProsesPendidikan Kesetaraan Program Pendidikan Sekolah Dasar Non-Formal, B dan C. Jakarta : Depdiknas

Direktorat Pendidikan Kesetaraan. (2010).Pedoman Penyelenggaraan Program Paket C Umum. Jakarta: Kemendiknas

Kamil, Mustofa. 2009. Pendidikan Nonformal Pengembangan melalui Pusat Kegiatan Belajar Masyarakat (PKBM) di Indonesia (Sebuah pembelajaran dari Kominkan Jepang).Bandung : Alfabeta.

Moeheriono. (2010). Pengukuran KinerjaBerbasis Kompetensi. Bogor: Ghalia Indonesia.

T.Sulistyianingsih ,(2013) Ipteks Bagi Pusat Kegiatan Belajar Masyarakat (PKBM) Dedikas Volume 10, Mei 2013: $65-72$

Vena Ariyani Diyanti, (2014),Hubungan Kompetensi Tutor dengan Motivasi Belajar Peserta Didik, E Jurnal UNS

Yunita Martyastuti, 2014.Kinerja Tutor Program Pendidikan Paket C (Umum)Dalam Melaksanakan Tugas Pokok Di SanggarKegiatan Belajar (Skb) Kabupaten Wonogiri, E Journal UNS 